Article

\title{
Food Intervention with Folate Reduces TNF- $\alpha$ and Interleukin Levels in Overweight and Obese Women with the MTHFR C677T Polymorphism: A Randomized Trial
}

\author{
Jéssica Vanessa de Carvalho Lisboa ${ }^{1, *}$, Marina Ramalho Ribeiro ${ }^{1}$, \\ Rafaella Cristhine Pordeus Luna ${ }^{1}$ (D), Raquel Patrícia Ataíde Lima ${ }^{1}$, \\ Rayner Anderson Ferreira do Nascimento ${ }^{2}$, Mussara Gomes Cavalcante Alves Monteiro ${ }^{1}$, \\ Keylha Querino de Farias Lima ${ }^{1}$, Carla Patrícia Novaes dos Santos Fechine ${ }^{1}$, \\ Naila Francis Paulo de Oliveira ${ }^{3}$ (D), Darlene Camati Persuhn ${ }^{1}$, Robson Cavalcante Veras ${ }^{1}$ (D), \\ Maria da Conceição Rodrigues Gonçalves ${ }^{1}$, Flávia Emília Leite de Lima Ferreira ${ }^{1}$ D, \\ Roberto Teixeira Lima ${ }^{1}$, Alexandre Sérgio da Silva ${ }^{1}$ (D), Alcides da Silva Diniz ${ }^{4}$, \\ Aléssio Tony Cavalcanti de Almeida ${ }^{5}$, Ronei Marcos de Moraes ${ }^{6}$, Eliseu Verly Junior ${ }^{7}$ (i) and \\ Maria José de Carvalho Costa ${ }^{1}$ \\ 1 Postgraduate Program in Nutrition Sciences, Health Sciences Center, Federal University of Paraíba, \\ João Pessoa 58059-900, Brazil; nutri.marinaramalho@gmail.com (M.R.R.); \\ rafaellacpluna@gmail.com (R.C.P.L.); raquelpatriciaal@hotmail.com (R.P.A.L.); \\ mussara.monteiro@hotmail.com (M.G.C.A.M.); k_farias1@hotmail.com (K.Q.d.F.L.); \\ carlafechine@hotmail.com (C.P.N.d.S.F.); darlenecp@hotmail.com (D.C.P.); drrobveras@gmail.com (R.C.V.); \\ mariadaconceicaorgoncalves@gmail.com (M.d.C.R.G.); flaemilia@gmail.com (F.E.L.d.L.F.); \\ robertotexlima@gmail.com (R.T.L.); alexandresergiosilva@yahoo.com.br (A.S.d.S.); \\ mjc.costa@terra.com.br (M.J.d.C.C.) \\ 2 Postgraduate Program in Molecular and Human Biology, Center of Exact and Natural Sciences, \\ Federal University of Paraíba, João Pessoa 58059-900, Brazil; raynerbiomedicina@gmail.com \\ 3 Departament of Molecular Biology, Federal University of Paraíba, João Pessoa 58059-900, Brazil; \\ nailafpo@gmail.com \\ 4 Postgraduate Program in Nutrition Sciences, Federal University of Pernambuco, Recife 50670901, Brazil; \\ diniz.alcides@hotmail.com \\ 5 Department of Economics, Postgraduate Program in App1lied Economics and Economics of the Public \\ Sector, Center for Applied Social Sciences, Federal University of Paraíba, João Pessoa 58059-900, Brazil; \\ alessiotony@gmail.com \\ 6 Postgraduate Program in Health Decision Models, Federal University of Paraíba, João Pessoa 58059-900, \\ Brazil; ronei@de.ufpb.br \\ 7 Department of Epidemiology, Institute of Social Medicine, State University of Rio de Janeiro, \\ Rio de Janeiro 20550-900, Brazil; eliseujunior@gmail.com \\ * Correspondence: jessicavlisboa@hotmail.com
}

Received: 10 July 2019; Accepted: 30 August 2019; Published: 30 January 2020

\begin{abstract}
Methylenetetrahydrofolate reductase (MTHFR) C677T polymorphism associated with body fat accumulation could possibly trigger an inflammatory process by elevating homocysteine levels and increasing cytokine production, causing several diseases. This study aimed to evaluate the effects of food intervention, and not folate supplements, on the levels of tumor necrosis factor- $\alpha$ (TNF- $\alpha$ ), interleukin-6 (IL-6), and interleukin-1 $\beta$ (IL-1 $\beta$ ) in overweight and obese women with the MTHFR C677T polymorphism. A randomized, double-blind eight-week clinical trial of 48 overweight and obese women was conducted. Participants were randomly assigned into two groups. They received $300 \mathrm{~g}$ of vegetables daily for eight weeks containing different doses of folate: $95 \mu \mathrm{g} /$ day for Group 1 and $191 \mu \mathrm{g} /$ day for Group 2. MTHFR C677T polymorphism genotyping was assessed by digestion with HinfI enzyme and on $12 \%$ polyacrylamide gels. Anthropometric measurements, 24-h dietary
\end{abstract}


recall, and biochemical analysis (blood folic acid, vitamin B12, homocysteine (Hcy), TNF- $\alpha$, IL-1 $\beta$, and IL-6) were determined at the beginning and end of the study. Group 2 had a significant increase in folate intake $(p<0.001)$ and plasma folic acid $(p<0.05)$ for individuals with the cytosine-cytosine (CC), cytosine-thymine (CT), and thymine-thymine (TT) genotypes. However, only individuals with the TT genotype presented reduced levels of Hcy, TNF- $\alpha$, IL-6, and IL-1 $\beta(p<0.001)$. Group 1 showed significant differences in folate consumption $(p<0.001)$ and folic acid levels $(p<0.05)$ for individuals with the $\mathrm{CT}$ and TT genotypes. Food intervention with folate from vegetables increased folic acid levels and reduced interleukins, TNF- $\alpha$, and Hcy levels, mainly for individuals with the TT genotype.

Keywords: interleukins; tumor necrosis factor-alpha; dietary intervention; polymorphism; genetic variants; folate; overweight; obesity

\section{Introduction}

Women with an unbalanced diet in calories could have an excessive accumulation of body fat, especially in the abdominal circumference, and an elevated body mass index (BMI). This nutritional status of overweight and obesity generates systemic subclinical inflammation from the adipose tissue. In this situation, nuclear factor kappa-light-chain-enhancer (NF- $k B$ ) of the active B cell pathway increases cytokine synthesis. Thus, this inflammation increases the production of reactive oxygen species (ROS), triggering oxidative stress, and as a consequence, there is a higher production of cytokines, creating a vicious cycle. In addition, another factor contributing to oxidative stress is the high level of homocysteine (Hcy) in the blood. Hcy, a metabolite derived from folate metabolism, may be increased in the presence of methylenetetrahydrofolate reductase (MTHFR) C677T polymorphism [1-3].

The C677T polymorphism (rs1801133) consists in nonsynonymous substitution (alanine to valine exchange at the 222nd codon - Ala222Val) in the exon 4 of the MTHFR gene, and as a result, the enzyme methylenetetrahydrofolate reductase (MTHFR) produced is very thermolabile and with decreased activity [4]. Then, with reduced activity, this key enzyme in folate metabolism is not able to perfectly catalyze the 5,10-methylenetetrahydrofolate (MTHF) reduction reaction in 5-MTHF and donate a methyl (CH3) group to the Hcy remethylation pathway in methionine, leading to hyperhomocysteinemia [4-6]. The high level of this metabolite (Hcy) leads to oxidative stress and also contributes to the elevation of inflammatory biomarkers, such as tumor necrosis factor- $\alpha$ (TNF- $\alpha$ ), interleukin-6 (IL-6), and interleukin-1 $\beta$ (IL-1 $\beta$ ) [7-12]. Furthermore, high Hcy oxidation and body fat accumulation could lead to cytokine-mediated inflammation, and an increase in the oxidative stress. In addition, a balanced diet rich in antioxidants and anti-inflammatory nutrients like folate might be necessary to reduce this damage and also to avoid the C677T polymorphism effects [3,13-18].

There is a difference between the terms folate and folic acid. Folate is a generic term used for compounds that have similar vitamin activity to pteroylpolyglutamates, which is used to describe the vitamins found naturally in food. The term folic acid, pteroylmonoglutamic acid (PGA), represents the synthetic form added to supplements/medication and fortified foods and is used to designate the blood levels of this vitamin [19].

Regardless of the source, the importance of folate from foods and folic acids found in fortified foods is due to the fact that they can directly influence the levels of folic acid and Hcy in blood, which could be affected by polymorphisms in genes encoding enzymes related to folate metabolism and absorption (MTHFR, among other genes) [19]. Therefore, lower folate intake should be avoided in adult women, especially those with this polymorphism, through daily consumption of adequate amounts of this nutrient ( $400 \mu \mathrm{g}$ of folate). It could be a way to maintain the immune system balanced, positively impacting the blood folic acid levels, and providing anti-inflammatory and antioxidant effects against inflammation [20-22]. 
Thus, the aim of this original study was to verify the influence of the MTHFR C677T polymorphism on the effect of diet intervention with folate from food sources on inflammatory biomarkers in women with overweight or obesity, providing dietary recommendations according to the genetic profile to improve health and longevity.

\section{Materials and Methods}

\subsection{Study Characterization}

A double-blind, randomized, eight-week intervention study related to the population-based study "Second Cycle of Diagnosis and Intervention on the Diet, Nutrition, and Most Prevalent Non-communicable Diseases in the Population of João Pessoa, Paraíba" (II DISANDNT/PB) was initiated in May 2015 and completed in May 2016 [23,24].

In this study, questionnaires were used to collect information about the socio-economic, demographic, and epidemiological status, anthropometric evaluation, lifestyle, 24-h dietary recall (24HR), and hematological and biochemical examinations. Thus, the questionnaires provided a rich database that encompassed all socioeconomic levels and age groups and were representative of the population of the eastern and western zones of João Pessoa city, Paraíba.

Based on information from the city, it was found that a number greater than 10,000 inhabitants and sample fractions less than $5 \%$ were needed; therefore, a finite population correction factor was unnecessary. Thus, setting the minimum sample required for an estimation of the population parameter to a level of reliability of $95 \%$ (corresponding to a critical value table $Z(\alpha / 2)$ of 1.96 ) was performed using the following calculation procedure [25].

$$
n^{*}=\frac{\hat{\sigma}^{2} Z_{\alpha / 2}^{2}}{E^{2}}
$$

Therefore,

$$
n^{*}=\frac{2.601,93^{2} \times 1,96^{2}}{332^{2}} \approx 236
$$

\subsection{Ethics Statement}

After assessing the inclusion criteria and genotypes for the MTHFR gene containing the C677T polymorphism, the researchers invited individuals to participate in the intervention, explained the aims of the study which were in accordance with the ethical guidelines, and obtained signed written consent from those who agreed to participate. The study was conducted in accordance with the Declaration of Helsinki. The study was submitted to and approved by the Research Ethics Committee of the University of Paraíba under protocol number 0569/15 and was registered in Clinical Trials under the ID number: NCT03186196.

\subsection{Population and Sampling}

The intervention was carried out using a randomly selected sample based on articles published on dietary intervention versus polymorphism [26-28]. The final sample comprised 48 women with overweight and obesity, with ages between 20 and 59 years who were participants of the II DISANDNT/PB study. Thus, setting the minimum sample required for the estimation of the population parameter, the following calculation procedure was used:

$$
\mu=\left((Z \alpha / 2+Z \beta / 2)^{2} \times\left(d p 1^{2}+d p 2^{2}\right)\right) /(\mu 1-\mu 2)^{2}
$$

Using the statistical program $\mathrm{R}$ and the effect size model of Cohen [29], as well as adopting the parameters of means and standard deviation (SD), we calculated the ex-post statistical power 
of the sample (whose power benchmark was at least $80 \%$ ). The effect size test result is shown in Tables 1 and 2.

Table 1. Size Effect.

\begin{tabular}{cccccc}
\hline Group & Gene & est_d & n & Significance & Power \\
\hline 2 & CC & 1.48 & 8 & $5 \%$ & $94.5 \%$ \\
\hline 2 & CT & 1.96 & 8 & $5 \%$ & $99.7 \%$ \\
\hline 2 & TT & 1.89 & 8 & $5 \%$ & $99.5 \%$ \\
\hline 1 & CC & 0.43 & 8 & $5 \%$ & $18.5 \%$ \\
\hline 1 & CT & 0.69 & 8 & $5 \%$ & $78.7 \%$ \\
\hline 1 & TT & 1.40 & 8 & $5 \%$ & $92.1 \%$ \\
\hline
\end{tabular}

Table 2. Analysis of the mean and standard deviation.

\begin{tabular}{ccccccc}
\hline Group & Gene & $\mathbf{n}$ & SD_Before FA & Mean_Before FA & SD_After FA & Mean_After FA \\
\hline 2 & CC & 8 & 5.30 & 12.95 & 7.27 & 22.22 \\
\hline 2 & CT & 8 & 1.62 & 13.49 & 3.10 & 18.11 \\
\hline 2 & TT & 8 & 5.12 & 16.53 & 4.36 & 25.48 \\
\hline 1 & CC & 8 & 4.09 & 13.18 & 3.79 & 14.89 \\
\hline 1 & CT & 8 & 3.98 & 13.32 & 4.96 & 16.40 \\
\hline 1 & TT & 8 & 4.60 & 15.01 & 6.30 & 22.63 \\
\hline
\end{tabular}

$\mathrm{FA}=$ Blood Folic Acid; $\mathrm{SD}=$ standard deviation.

As shown in Table 1 above, after the ex-post effect size test, when group separation took place and the power of the sample was analyzed, all genotypes in Group 2 (191 $\mu \mathrm{g} /$ day of folate from the $300 \mathrm{~g}$ of vegetables and legumes) presented a power of significance higher than $80 \%$, showing that 8 people per genotype were sufficient for the results presented in this post-intervention group.

In Group 1, the power of significance was not observed in individuals with the CC genotype; however, for individuals with the TT genotype, the power of significance was greater than $80 \%$ and approximately $80 \%$ for individuals with the CT genotype.

\subsection{Inclusion and Exclusion Criteria}

The inclusion criteria were: women with BMI $>25 \mathrm{~kg} / \mathrm{m}^{2}$ from different socioeconomic conditions and with preserved cognitive state. The exclusion criteria were set as follows: adult women alcoholics, smokers, or neuropsychiatric disorder-diagnosed patients using medications (e.g., prednisone, hydrocortisone, dexamethasone, chloramphenicol, and acetylsalicylic acid) that interfere with folic acid metabolism (during the last three months), using a multivitamin, mineral, anorexigenic, or anabolic supplement, diagnosed with chronic diseases affecting the endocrine and metabolic system, and pregnant or planning to become pregnant during the study period.

\subsection{Experimental Protocol}

Initially, the women were evaluated based on the eligibility criteria, and then, the women who consented to participate were advised to maintain a stable weight, eating habits, and levels of physical activity with respect to the data found at the baseline [30]. In addition to these guidelines, they underwent a baseline assessment with an individual dietary plan one week before beginning the dietary intervention based on the Therapeutic Lifestyle Modifications, US National Cholesterol Education Program (NCEP) [31] and American Heart Association (AHA) models [32]. 
Participants who wanted to change their eating habits except for folate, the frequency of physical activity or body weight during the study period were excluded from the study [30]. All the individual's medical therapies remained unchanged throughout the study.

After application of the first R24h, biochemical tests were performed, and the C677T polymorphism in the MTHFR gene was analyzed; then, after 15 days, another R24h was applied to enable an analysis of the food intake before the intervention period. Thus, the participants were submitted to the baseline to standardize food consumption before the beginning of the dietary intervention.

At the end of the one-week intervention, each participant among the 48 women were randomized into intervention groups: Group 1 (G1): 24 women, subdivided in three subgroups of eight by genotypes (normal homozygous CC genotype, heterozygous CT genotype, and homozygous TT genotype); same for Group 2 (G2): 24 women, subdivided in three subgroups of eight by genotypes (CC genotype, CT genotype, TT genotype). The randomization was performed using STATA software version 14.0 for Windows.

To control the usual food intake, different criteria were respected. The total energy expenditure was calculated based on the Dietary Reference Intakes (DRIs) [21,33]. The macronutrients were distributed as recommended by the AHA [32]. The equivalent system proposed by Costa et al. [34] was used to calculate, analyze, and evaluate the intake of nutrients of the recommended diet: carbohydrates: $45 \%-65 \%$ (55\% recommended); protein: $10 \%-35 \%$ (15\% recommended); and total fat: $25 \%-35 \%$ (30\% recommended).

In addition, both experimental groups received individually designed diets with nutritional guidance (containing folate-rich vegetables and grains in addition to other food groups) to control daily folate intake. The folate intake was evaluated by four $24 \mathrm{~h}$ recalls, analyzed by the DietWin nutritional software (Porto Alegre, RS) and the multiple source method (MSM).

Individuals from both groups were encouraged to consume folic acid-fortified foods to achieve Estimated Average Requirement, EAR ( $\geq 400 \mu \mathrm{g} /$ day folate); Group 1 (191 $\mu \mathrm{g} /$ day folate) and Group 2 $(95 \mu \mathrm{g} /$ day folate). These quantities were based on the Diabetes and plant food products (DIAPLANT), a randomized prospective controlled trial study of Switzeny et al. [30], who analyzed the effect of a diet containing $153 \mu \mathrm{g} \pm 82.32 \mu \mathrm{g}$ of folate from $300 \mathrm{~g}$ of vegetables in women, observed good results with an increase in methylation of the DNA promoter region in the mutL homolog 1 (MLH1) gene in individuals with diabetes mellitus type 2 (DMT2).

\subsection{Dietary Intervention Composition}

Standardization of the weighing and preparation of the vegetables used in this intervention study was carried out by a commercial restaurant in the city of João Pessoa, whose specialty is the sale of salads, supervised by a professional nutritionist. Vegetables were duly packed in individual plastic containers, transported with adequate refrigeration, and delivered daily to the participants' residence for two months ( 8 weeks) by the responsible researchers, who were not aware of the food, quantities or group of each participant.

In this double-blinded study, neither the nutritionists nor participants, who were divided into two groups, had access to the following information: quantity and type of vegetables of each container, and which group received the high and low dose of folate. Only the owner of the restaurant knew all this information and labeled the containers with number 1 or 2, not necessarily indicating Groups 1 or 2.

\subsection{Data Collection}

The II DISANDNT/PB team, comprising researchers from the Graduate Program in Nutrition Sciences, University of Paraíba, were duly trained at the beginning of the data collection period. This team was responsible for the application of the food consumption questionnaires (R24h and food frequency questionnaire) and the biochemical analyses during home visits. 
For nutrition assessment, the weight and height measurements were collected in triplicate to average these three values. The body mass index (BMI) was calculated using the body-weight formula $(\mathrm{kg})$ divided by the square of the height (meters) [35].

Biochemical analyses of folic acid, vitamin B12, Hcy, TNF- $\alpha$, and the pro-inflammatory cytokines interleukins IL- $1 \beta$ and IL-6 were performed at the end of the application of the fourth R24h. An anthropometric evaluation was performed during the data collection from the II DISANDNT/PB study and after the nutritional intervention.

Hcy levels were measured using high-performance liquid chromatography (HPLC), the media plasma homocysteine for women was $7.2 \mu \mathrm{mol} / \mathrm{L}$ [36]. The Access Folic Acid assay is a paramagnetic particle, chemiluminescent immunoassay for the quantitative determination of folic acid levels in human serum and plasma (heparin) or red blood cells (RBC) using the Access Immunoassay Systems. Folic acid levels in serum and plasma or RBC are used to assess folate status. The serum folic acid level is an indicator of recent folate intake, while a low $\mathrm{RBC}$ folate value could indicate a prolonged folate deficiency. Thus, serum levels of folic acid were estimated using the commercial kit (Access Folic Acid Kit [A98032]; Beckman Coulter, Fullerton, CA, USA). Folate deficiency was defined as $<3.10 \mathrm{ng} / \mathrm{mL}$ with an analytical sensitivity of $0.5 \mathrm{ng} / \mathrm{mL}$, and the laboratory reference value for vitamin $\mathrm{B} 12$ is 211-911 pg/mL [37]. The quantitative dosages of TNF- $\alpha$ and interleukins were determined using $25 \mu \mathrm{L}$ of the sample serum incubated for $3 \mathrm{~h}$ at room temperature with shaking using a chemiluminescent solid-phase IMMULITE/IMMULITE 1000 system (Siemens Medical Solutions Diagnostics, Los Angeles, CA, USA). The reference value for TNF- $\alpha$ was $<8.1 \mathrm{pg} / \mathrm{mL}$. For interleukins, most laboratories indicated the normal reference values as less than $5.0 \mathrm{pg} / \mathrm{mL}$ for IL- $1 \beta$ and 0 to $5.9 \mathrm{pg} / \mathrm{mL}$ for IL-6 [38-42].

\subsection{Food Consumption}

The evaluation of food consumption was carried out by applying four R24h, one weekend, and one weekday, performed with a 15-day interval before the beginning of the intervention. The aim of this procedure was to establish the participants' dietary habits as a basis for the menu definition and intake comparison at the end of the study. A third R24h was performed after the plateau week to investigate adherence to the nutritional instructions that were given. A fourth R24h was performed at the end of the eight-week intervention to analyze the participants' usual caloric and nutrient intake to establish whether they had adhered to the recommendations and whether changes in their global and folate dietary intake had occurred after the intervention [3].

The recalls were completed by the staff according to the reports of the interviewed individuals, including the following information: mealtime and identification of the drink or food ingested with their specific characteristics, such as the type, ingredients of the preparations, brand, method of preparation, amount consumed, portion size and home measurements.

To effectively quantify the size of the portions consumed and reduce the possible memory faults of the interviewees, an album with food figures representing the home measures at different dimensions (small, medium, large, and extra-large) that were drawn according to the real weight of the average consumption of the food validated for this population was used [43,44].

All ingredients and amounts of the food preparations were detailed, and the foods were analyzed by Dietwin (Porto Alegre, Rio Grande do Sul, Brazil), a nutrition software platform containing approximately 5230 foods and various recipes. All the registrations were based on the fourth version of the TACO and DIETWIN tables, a compilation of the following tables: Brazilian Institute of Geography and Statistics (IBGE), United States Department of Agriculture (USDA), CENEXA, German, General Repertory of Food and Revenue Technical Data Sheets. The USDA table [45] and Dietwin were used to analyze folate food consumption.

To estimate the variability of the habitual/daily intake of nutrients and to correct the intrapersonal variance, we used the R24h recalls and Multiple Source Method (MSM), a new statistical method from the European Prospective Investigation into Cancer and Nutrition $[37,38,46]$ to estimate the usual 
dietary intake of nutrients and foods for populations and individuals, including episodically consumed food. Available online (https://msm.dife.de/Tps/msm/) [47].

\subsection{Collection and Isolation of Leukocyte DNA}

The leukocytes used to isolate DNA were obtained by a venous puncture to collect whole blood in sterile 4-mL tubes with $7.2 \mathrm{mg}$ of K3-ethylenediaminetetraacetic acid (EDTA). All blood samples collected were analyzed at the Department of Molecular Biology of the Federal University of Paraíba (UFPB) following the protocol adapted from Miller, Dykes, Polesky [48].

Initially, to lyse red cells, lysis solution 1 , containing $10 \mathrm{mM}$ Tris- $\mathrm{HCl}$ at $\mathrm{pH} 8,5 \mathrm{mM}$ EDTA, $0.3 \mathrm{M}$ sucrose, and $1 \%$ Triton- $X-100$, was used, followed by centrifugation at $3200 \mathrm{rpm}$ and discarding the supernatant.

To obtain the precipitate of pure leukocytes, the procedure with lysis solution 1 and centrifugation was performed three times. The leucocyte precipitate was then resuspended in lysis solution 2, containing $10 \mathrm{mM}$ Tris- $\mathrm{HCl}$ at $\mathrm{pH} \mathrm{8,0.5 \%} \mathrm{sodium} \mathrm{dodecyl} \mathrm{sulphate} \mathrm{(SDS),} 5 \mathrm{mM}$ EDTA, $0.2 \mu \mathrm{g}$ proteinase K (Invitrogen, Carlsbad, CA, USA), and incubated in a water bath for $7 \mathrm{~h}$ at a temperature of $55^{\circ} \mathrm{C}$. Next, $500 \mu \mathrm{L}$ of the aqueous solution containing $1 \mathrm{mM}$ EDTA and $7.5 \mathrm{M}$ ammonium acetate was added, with further centrifugation at $14,000 \times g$ (gravity force) for $10 \mathrm{~min}$ at $4{ }^{\circ} \mathrm{C}$. Next, $700 \mu \mathrm{L}$ of the supernatant was transferred to another sterile tube, and then, $540 \mu \mathrm{L}$ of isopropanol was added to precipitate the DNA.

Finally, DNA was extracted from the precipitate using the following procedure: washing with $70 \%$ ethanol, centrifugation for $5 \mathrm{~min}$ at 12,000 $\mathrm{g}$ (gravity force), drying, and resuspension in Tris-EDTA buffer $\mathrm{pH} 8.0$ [48]. If it was not possible to perform all these procedures for DNA extraction on the same day, the samples were stored in the freezer at $-20^{\circ} \mathrm{C}$.

\subsection{Analysis of the C677T Polymorphism of the MTHFR Gene}

Two primers [4] were used:

5'-TGAAGGAGAAGGTGTCTGCGGGA-3' (sense); 5'-AGGACGGTGCGGTGAGAGTG-3' (antisense).

Next, the amplification process was conducted in a thermocycler using an initial denaturing condition at $94{ }^{\circ} \mathrm{C}$ for $10 \mathrm{~min}$, followed by 35 cycles of denaturation at $94{ }^{\circ} \mathrm{C}$ for $30 \mathrm{~s}$, annealing at $61{ }^{\circ} \mathrm{C}$ for $30 \mathrm{~s}$, extension at $72{ }^{\circ} \mathrm{C}$ for $30 \mathrm{~s}$, and a final extension step at $72{ }^{\circ} \mathrm{C}$ for $10 \mathrm{~min}$.

Thereafter, a 198-bp product was obtained and was subsequently digested with HinfI enzyme, which recognizes and cleaves the polymorphic $\mathrm{T}$ allele by dividing it into two fragments: a $175 \mathrm{bp}$ fragment and a $23 \mathrm{bp}$ fragment. The ancestral allele $\mathrm{C}$ was $198 \mathrm{bp}$ in size.

For the analysis of the genotypes, the samples were analyzed on $12 \%$ polyacrylamide gels. Finally, the gel was colored with $0.5 \%$ silver nitrate to allow the evaluation of the genotypes [49].

\subsection{Statistical Analysis}

The characteristics of the sample were expressed using descriptive statistics. Biomarkers were described as means and standard deviation or log-transformed and expressed in geometric mean and $95 \%$ CI.

It was verified that the distribution of the data was not strongly deviated from asymmetry. Therefore, the Central Limit Theorem was used, which states that for a sufficient sample size, $n=48$ in the current study, the sample mean has an approximately normal distribution. The symmetry of the biomarkers was verified separately, one by one, adapting to the use of the Central Limit Theorem.

To analyze the initial and final values after the dietary intervention, the normal and non-normal biomarkers were analyzed according to Student's t-Test. Student's t-test can be used for non-normal biomarkers, provided that for the sample size, the biomarker is close to normality so that the sample mean has a normal distribution with the same mean of the biomarker and variance as the variance of 
the biomarker divided by the sample size. The Central Limit Theorem states that for a significantly large sample, the sample mean has an approximately normal distribution.

To compare the biomarkers of the two groups by genotyping, we used the paired student t-test, making a peer-to-peer analysis of individuals from different groups and genotypes before and after the intervention. All statistical analyses were performed using Software R version 3.3.2 (Available at https://cran.r-project.org/), adopting the significance level of 5\% to reject the null hypothesis.

\section{Results}

Two hundred and thirty-eight $(\mathrm{n}=238)$ women classified as overweight or obese were screened for eligibility, but 190 did not meet the inclusion and exclusion criteria, resulting in a sample of 48 women. Participants were randomly assigned in the $G 1(n=24)$ or $G 2(n=24)$ group. The final sample comprised 48 women (Figure 1).

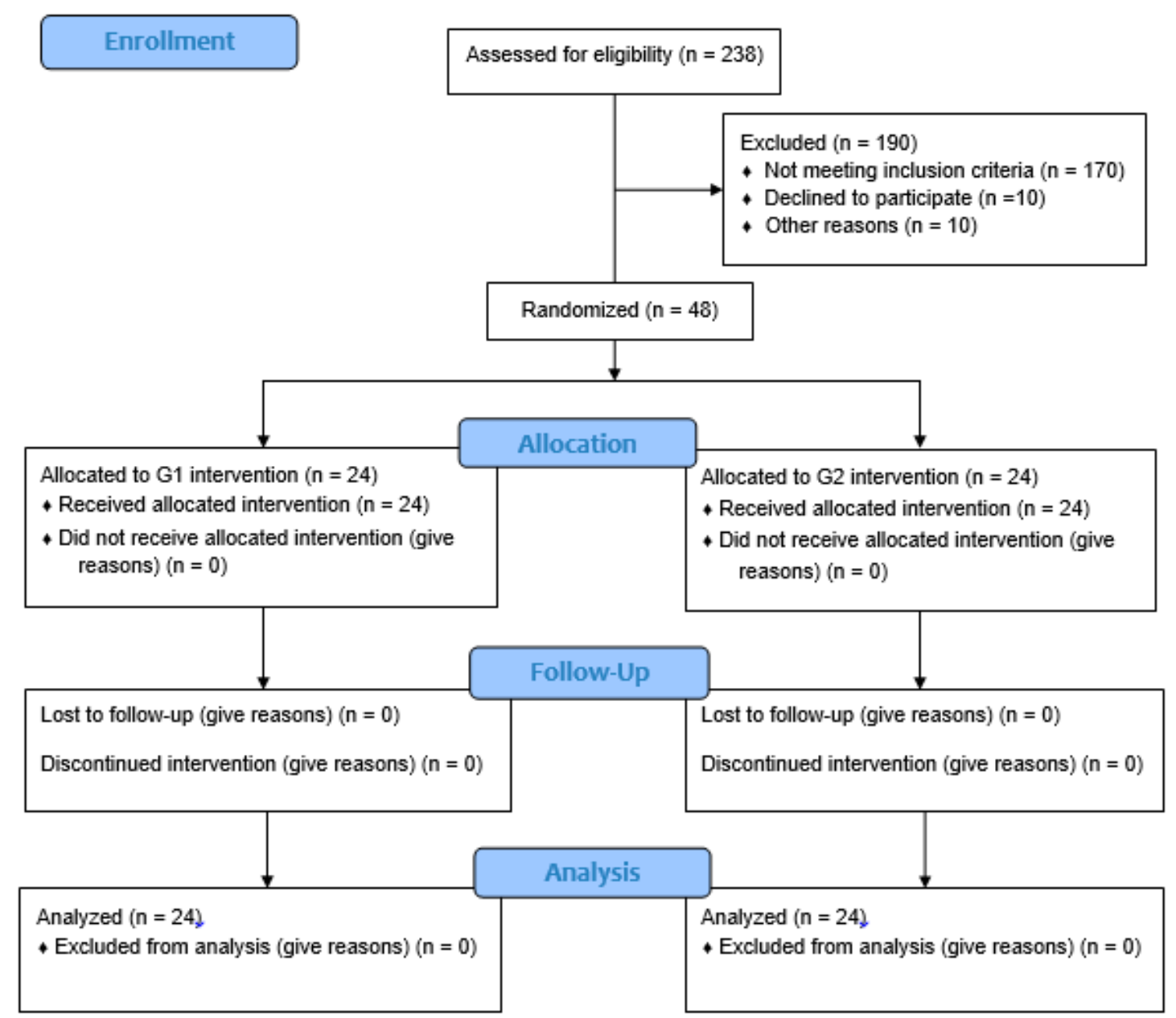

Figure 1. Participant flow through the study. G1, Group 1; G2, Group 2.

\subsection{General Characteristics of the Participants by Groups}

The final sample was composed of 48 overweight and obese women between the ages of 20 and 59 years for both groups (G1-95 $\mu \mathrm{g}$ and G2-191 $\mu \mathrm{g})$.

In Table 3, for all the analyzed variants (Folate, Folic Acid, Vitamin B12, Hcy, TNF- $\alpha$, and IL-1 $\beta$ ), there was no significant difference between the groups before the dietary food intervention ( $p$-value $>$ 0.05). The data showed that the groups were homogeneous at this point.

Regarding the BMI, in G,1 we observed that $54 \%$ of the sample was lower than the described mean and $45.8 \%$ had results higher or equal to the average. For G2, 33\% presented lower BMI when 
compared to the mean, and $66.7 \%$ higher or equal to the average BMI described in the table. The lower limit was $26 \mathrm{~kg} / \mathrm{m}^{2}$ and $27 \mathrm{~kg} / \mathrm{m}^{2}$ and higher $38 \mathrm{~kg} / \mathrm{m}^{2}$ and $50 \mathrm{~kg} / \mathrm{m}^{2}$ for G1 and G2, respectively.

Table 3. General characteristics of the participants by groups before the feeding intervention.

\begin{tabular}{cccc}
\hline Biomarkers & Group 1 $(\mathbf{9 5} \mu \mathrm{g} / \mathrm{Day})$ & Group $\mathbf{2}(\mathbf{1 9 1} \boldsymbol{\mu g} / \mathbf{D a y})$ & $\boldsymbol{p}$-Value \\
\hline Age $(\mathrm{years})$ & $44.33 \pm 9.26$ & $44.88 \pm 12.47$ & 0.8802 \\
\hline BMI $\left(\mathrm{kg} / \mathrm{m}^{2}\right)$ & $30.47 \pm 4.82$ & $29.88 \pm 3.01$ & 0.6236 \\
\hline WC $(\mathrm{cm})$ & $91.78 \pm 12.02$ & $91.63 \pm 7.96$ & 0.9600 \\
\hline Folate $(\mu \mathrm{g})$ & $150.90 \pm 42.73$ & $144.40 \pm 43.47$ & 0.6034 \\
\hline Folic Acid $(\mu \mathrm{g} / \mathrm{mL})$ & $13.83 \pm 4.13$ & $14.32 \pm 4.46$ & 0.6222 \\
\hline Vitamin B12 $(\mathrm{pg} / \mathrm{mL})$ & $304.66 \pm 133.05$ & $253.14 \pm 103.58$ & 0.1417 \\
\hline Homocysteine $(\mu \mathrm{mol} / \mathrm{L})$ & $11.65 \pm 5.99$ & $9.64 \pm 2.44$ & 0.1404 \\
\hline TNF- $\alpha(\mathrm{pg} / \mathrm{mL})$ & $6.14 \pm 7.26$ & $6.51 \pm 7.90$ & 0.8661 \\
\hline IL-1 $\beta(\mathrm{pg} / \mathrm{mL})$ & $3.88 \pm 3.90$ & $5.11 \pm 4.92$ & 0.3429 \\
\hline IL-6 $(\mathrm{pg} / \mathrm{mL})$ & $4.42 \pm 3.85$ & $4.49 \pm 3.47$ & 0.9894 \\
\hline
\end{tabular}

Values expressed as mean and standard deviation $( \pm \mathrm{SD})$. TNF- $\alpha=$ tumor necrosis factor-alpha; BMI = Body Mass Index; IL = Interleukin; WC = waist circumference.

As for groups 1 and 2, it was observed that both of them presented reduced values of habitual folate intake according to the EAR ( $400 \mathrm{mcg} / \mathrm{day})$. For both groups, $37 \%$ of the samples obtained results higher than the average and $63 \%$ had values lower than the average. Regarding the results of blood folic acid, $70 \%$ (G1) and $62 \%$ (G2) showed values according to the reference. When analyzing the results for vitamin B12, it was observed that in G1, 30\% presented lower values when compared to the reference, and $58 \%$ of the samples were in agreement with the reference. For G2, 37\% were lower than the reference and $71 \%$ presented results according to the reference.

We also observed that $54 \%$ of the samples in G1 reached boundary values for the marker Hcy, and for G2, 75\% had higher values and $20 \%$ of the samples presented lower values when they were compared to the average. TNF- $\alpha$ presented $45 \%$ and $42 \%$ of the results higher than the reference for G1 and G2, respectively. For the last variable, IL-6 marker was higher in both groups, $54 \%$ in G1 and $42 \%$ in $\mathrm{G} 2$.

The mean for the IL-1 $\beta$ value in G1 pre-intervention was considered within the normal range $(<5.0 \mathrm{pg} / \mathrm{mL})$, but $50 \%$ presented results higher than the reference, while for $\mathrm{G} 2,62 \%$ had values higher than the reference. The mean of the IL-1 $\beta$ value in G2 pre-intervention was considered elevated $(>5.0 \mathrm{pg} / \mathrm{mL})$.

\subsection{Effect of Folate Intervention on Different Genotypes of MTHFR C677T and Inflammatory Biomarkers}

This novel intervention with folate from food sources positively interfered with the inflammatory status of the sample when the MTHFR genotypes were compared before and after the intervention, predominantly influencing Group $2(191 \mu \mathrm{g} /$ day $)$ and the individuals with the TT genotype with a reduction in Hcy, TNF- $\alpha$, IL-6, and IL-1 $\beta$. It was also observed that the folate intake and folic acid serum levels were increased in all genotypes of this group. In Group $1(95 \mu \mathrm{g} / \mathrm{day})$, there was an increase in folate intake in individuals with the CC and TT genotypes with higher blood folic acid concentrations for individuals with the $\mathrm{CT}$ and TT genotypes. Although there was no reduction in Hcy or inflammatory parameters in TT or other genotypes. The best results in inflammatory parameters and Hcy values were with the $191 \mu \mathrm{g} /$ day diet in the MTHFR 677C > T dependent genotypes, because of a possible increase in circulating folic acid in the blood.

Table 4 shows that higher concentrations of folate intake had a significant impact on the response of folic acid in the blood, homocysteine concentrations, and inflammatory parameters. 
Table 4. Values of vitamins, homocysteine, and inflammatory markers, separated by the Methylenetetrahydrofolate reductase MTHFR genotypes, groups and pre and post-diet intervention with folate.

\begin{tabular}{|c|c|c|c|c|c|c|c|c|c|}
\hline \multicolumn{10}{|c|}{ Group $195 \mu \mathrm{g} /$ Day } \\
\hline & Pre & Post & $p$-value & Pre & Post & $p$-value & Pre & Post & $p$-value \\
\hline & $\mathrm{CC}$ & $\mathrm{CC}$ & & $\mathrm{CT}$ & CT & & TT & TT & \\
\hline Folate $(\mu \mathrm{g})$ & $149.0 \pm 14.43$ & $292.0 \pm 65.24$ & 0.0004 * & $170.0 \pm 50.43$ & $254.0 \pm 85.27$ & 0.0910 & $154.0 \pm 53.84$ & $316.0 \pm 63.06$ & 0.0003 * \\
\hline $\mathrm{FA}(\mu \mathrm{g} / \mathrm{mL})$ & $13.18 \pm 4.08$ & $14.88 \pm 3.79$ & 0.1318 & $13.32 \pm 3.97$ & $16.4 \pm 4.95$ & $0.0011 *$ & $15.00 \pm 4.60$ & $22.62 \pm 6.30$ & 0.0249 * \\
\hline Vit. B12 ( $\mu \mathrm{g} / \mathrm{mL})$ & $268.6 \pm 92.63$ & $271.0 \pm 92.16$ & 0.3185 & $345.5 \pm 179.14$ & $355.2 \pm 202.59$ & 0.7991 & $299.8 \pm 118.65$ & $273.6 \pm 83.60$ & 0.3162 \\
\hline Hcy $(\mu \mathrm{mol} / \mathrm{L})$ & $13.61 \pm 13.10$ & $7.83 \pm 2.51$ & 0.2408 & $10.98 \pm 6.11$ & $9.86 \pm 4.43$ & 0.6812 & $19.33 \pm 12.75$ & $14.91 \pm 10.40$ & 0.4603 \\
\hline $\mathrm{TNF}-\alpha(\mathrm{pg} / \mathrm{mL})$ & $5.80 \pm 8.33$ & $4.45 \pm 3.54$ & 0.6489 & $9.52 \pm 8.63$ & $2.84 \pm 2.09$ & 0.0517 & $3.10 \pm 2.34$ & $4.30 \pm 6.99$ & 0.5959 \\
\hline IL-6 (pg/mL) & $4.26 \pm 5.10$ & $4.48 \pm 2.29$ & 0.9184 & $5.16 \pm 1.60$ & $2.82 \pm 2.96$ & 0.0685 & $3.85 \pm 4.39$ & $3.29 \pm 3.07$ & 0.8310 \\
\hline $\mathrm{IL}-1 \beta(\mathrm{pg} / \mathrm{mL})$ & $3.50 \pm 4.44$ & $3.85 \pm 1.78$ & 0.8280 & $5.43 \pm 4.50$ & $1.55 \pm 1.79$ & $0.0224^{*}$ & $2.71 \pm 2.34$ & $3.69 \pm 4.58$ & 0.6713 \\
\hline \multicolumn{10}{|c|}{ Group $2191 \mu \mathrm{g} /$ Day } \\
\hline & Pre & Post & $p$-value & Pre & Post & $p$-value & Pre & Post & $p$-value \\
\hline & $\mathrm{CC}$ & $\mathrm{CC}$ & & CT & CT & & TT & TT & \\
\hline Folate $(\mu \mathrm{g})$ & $132.0 \pm 32.73$ & $352.0 \pm 73.07$ & 0.0000 * & $128.0 \pm 41.17$ & $410.0 \pm 372.35$ & $0.0000 *$ & $184.0 \pm 34.54$ & $376.0 \pm 68.32$ & 0.0000 * \\
\hline $\mathrm{FA}(\mu \mathrm{g} / \mathrm{mL})$ & $12.94 \pm 5.29$ & $22.21 \pm 7.26$ & $0.0033 *$ & $13.48 \pm 1.61$ & $18.11 \pm 3.10$ & $0.0016 *$ & $16.52 \pm 5.11$ & $25.48 \pm 4.35$ & 0.0046 * \\
\hline Vi. B12 ( $\mu \mathrm{g} / \mathrm{mL})$ & $251.8 \pm 113.13$ & $237.5 \pm 52.69$ & 0.7174 & $261.2 \pm 139.79$ & $258.0 \pm 113.03$ & 0.8429 & $246.3 \pm 52.71$ & $228.6 \pm 78.15$ & 0.6492 \\
\hline Hсу $(\mu \mathrm{mol} / \mathrm{L})$ & $8.97 \pm 1.52$ & $7.60 \pm 1.79$ & 0.1207 & $9.91 \pm 3.70$ & $8.01 \pm 2.27$ & 0.2374 & $10.05 \pm 1.66$ & $7.11 \pm 0.77$ & $0.0005^{*}$ \\
\hline $\mathrm{TNF}-\alpha(\mathrm{pg} / \mathrm{mL})$ & $7.73 \pm 12.34$ & $5.46 \pm 9.38$ & 0.5132 & $5.02 \pm 4.59$ & $1.66 \pm 2.31$ & 0.1614 & $6.78 \pm 5.24$ & $1.66 \pm 0.53$ & 0.0004 * \\
\hline IL-6 (pg/mL) & $3.93 \pm 4.70$ & $3.63 \pm 3.41$ & 0.8980 & $3.86 \pm 3.76$ & $1.84 \pm 2.03$ & 0.2224 & $5.67 \pm 0.93$ & $0.66 \pm 0.74$ & 0.0000 * \\
\hline $\mathrm{IL}-1 \beta(\mathrm{pg} / \mathrm{mL})$ & $3.17 \pm 5.74$ & $17.62 \pm 1.63$ & 0.2610 & $6.85 \pm 5.82$ & $3.01 \pm 3.43$ & 0.1565 & $5.32 \pm 2.20$ & $1.73 \pm 2.47$ & $0.0007^{*}$ \\
\hline
\end{tabular}

* All values are expressed as mean and standard deviation $( \pm \mathrm{SD}) \cdot p$-values refer to the Student's $\mathrm{t}$-test for paired sample mean differences. In all $\mathrm{t}$ statistics, the degree of freedom of the model was equal to 15. G1: $191 \mu \mathrm{g} /$ day of folate; G2: $95 \mu \mathrm{g} /$ day of folate. FA: folic acid ( $\mu \mathrm{g} / \mathrm{mL}$ ); Vit. = Vitamin; IL- interleukin; TNF: tumor necrosis factor; Hcy: homocysteine; CC, cytosine-cytosine; $\mathrm{CT}$, cytosine-thymine; TT, thymine-thymine. 
When analyzing the results from the biomarkers, G1 (95 $\mu \mathrm{g} /$ day folate) showed high levels of Hcy in individuals with the TT genotype, with a small and non-significant reduction $(p>0.005)$, and IL-1 $\beta$ levels that were borderline for individuals with the CT genotype, presenting reduction. In G2 (191 $\mu \mathrm{g} /$ day of folate), individuals with the TT genotype had a significant reduction in Hcy concentration $(p<0.0005)$, stabilizing at borderline mean levels. Regarding IL-6 and IL-1 $\beta$, the levels were borderline and reduced in individuals with the TT genotype. These results already show signs of subclinical inflammation.

In the diet with $95 \mu \mathrm{g} /$ day (Group 1), a significant increase of folate occurred in individuals with the CC and TT genotypes. For folic acid, a significant elevation was observed in individuals with the CT genotype, and a slight increase in individuals with the TT genotype. However, the impact of such elevation on inflammatory parameters could only be observed discreetly in individuals with the CT genotype.

On the other hand, in the diet with $191 \mu \mathrm{g} /$ day (Group 2), the elevation of folate intake and folic acid metabolites was significant in all genotypes. However, the reduction in homocysteine levels and all the inflammatory markers' activity occurred only in individuals with the TT genotype, suggesting that the benefits from the diet, at least as far as inflammation is concerned, are genotype-dependent.

Regarding the results of vitamin B12 in both groups, we did not observe any change in this parameter when comparing pre- and post-dietary intervention.

\section{Discussion}

Many studies have shown that an intervention with enriched folic acid diet resulted in positive health effects in adults with hyperhomocysteinemia and low folic acid levels carrying the MTHFR C677T polymorphism [50-57]. However, to date, no other study has presented significant results from a folate intervention on inflammatory biomarker levels of women carrying the MTHFR C677T polymorphism.

The folate diet was obtained from vegetables and legumes, offering an estimated average requirement (EAR) between $87.5 \%$ and 102.5\% (95-191 $\mu \mathrm{g} /$ day) over eight weeks. This diet was able to reduce Hcy, inflammatory biomarker levels, and also increase the folic acid concentration in young women with overweight or obesity. The effectiveness and adhesion to the intervention were facilitated by the researchers that provided an accessible intake of the five vegetable and legume servings/day (300 g per day) as recommended by the "Therapeutic Lifestyle Changes" model, US National Cholesterol Education Program (NCEP) [31], and American Heart Association [33].

Regarding folic acid content, individuals with the 677TT genotype from both groups (1 and 2) presented increased levels, but with different intensities-higher in G2 with an intake of $191 \mu \mathrm{g} / \mathrm{day}$ $(p<0.005)$ than in G1 containing $95 \mu \mathrm{g} /$ day $(p<0.05)$ - likely as a result of the different amounts administered in the intervention. This result corroborates those obtained by Tsang et al. [6] with a meta-analysis of trials and observational studies using folic acid supplementation.

Similar outcomes were found by Brouwer et al. [58] in a randomized control trial with 144 healthy women in Holland. The long-term folic acid supplementation (250 and $500 \mu \mathrm{g}$ of folic acid/day) for four weeks was able to increase the concentration of folic acid in serum and red blood cells (RBC). In another study conducted by Arias et al. [59], with a group of 34 young Colombian women at reproductive age, the supplementation of $400 \mu \mathrm{g} / \mathrm{day}$ of folic acid for three months showed a better response regarding folate intake and folic acid blood levels in individuals with the 677TT genotype when compared to the 677CC or 677CT genotypes. Corroborating these results, Anderson et al. [60] demonstrated with 142 participants that the increase in folic acid concentrations with $400 \mu \mathrm{g}$ supplementation depended on the MTHFR C677T genotype, with the 677TT genotype presenting a better response than individuals with the 677CC or 677CT genotypes.

In the present study, $54 \%$ of the G1 and $75 \%$ of the $\mathrm{G} 2$ reached the borderline reference values for Hcy, however, $20 \%$ of the G2 presented values below the borderline reference. Interestingly, Hcy levels were decreased only in G2 in individuals with the TT genotype, indicating that for this purpose, the diet was only effective under conditions where the folate bioavailability was low, i.e., in carriers of two 
alleles encoding the enzyme in the thermolabile version [61]. Hcy is a metabolite of the methionine remethylation pathway and has been considered a potential marker of methyl-THF formation, acting as a methyl group donor. Studies have indicated that higher Hcy levels (approximately 20\%) are associated with low folate levels in individuals with the MTHFR TT genotype. In this context, the MTHFR TT has a reduction of $70 \%$ of its catalytic activity caused by the C677T polymorphism [4]. Similar results of homocysteine concentrations demonstrating reduction after long-term supplementation with folic acid were found in many other studies [58,59,62,63], especially in individuals with the 677TT genotype $[55,60,64]$.

We also observed in our sample that obesity/overweight (elevated BMI and WC), associated with hyperhomocysteinemia caused by $\mathrm{C} 677 \mathrm{~T}$ polymorphism, can trigger inflammation and oxidative stress by activating the NF- $\mathrm{kB}$ signaling pathway $[65,66]$. Furthermore, the production of Reactive Oxygen Species (ROS) could selectively change the pattern of interleukins' expression [67-69] and tumor necrosis factor-alpha (TNF- $\alpha$ ). TNF- $\alpha$ is an important inflammatory marker that induces the synthesis of cytokine mediators IL- $1 \beta$ and IL- 6 [70,71], acting synergistically and intensifying inflammation [72-74]. Therefore, to disrupt the vicious cycle that could lead to the development of chronic disease, the reduction of this inflammation in women with the C677T polymorphism in the MTHFR gene is very important [75-77]. In the present study, we can infer that the folic acid intake did not alter the weight of women.

It is not surprising that the most robust response in terms of reduction of inflammatory mediators occurred under the conditions in which Hcy was decreased significantly-i.e., in individuals with the TT genotype and diet of $191 \mu \mathrm{g} /$ day. It was suggested that the observed effect occurred because, in individuals with the 677TT genotype only, there is a folate deficit. The deficit is caused by the MTHFR with reduced activity in the remethylation pathway and elevated Hcy, consequently leading to $\mathrm{CH} 3$-folate-limiting levels. Thus, in the present study, folate availability was sufficient to significantly reduce Hcy using supplementation longer than four weeks. The same results were demonstrated in the meta-analysis carried out by Colson et al. [64] and confirmed by other studies $[3,15,55,56,60,64,76]$, showing a reduction in inflammatory parameters, and suggesting that one effect is a consequence of the other.

In a previous work of the researcher's group presented by Ribeiro et al. [3], a similar intervention with vegetables and food was performed, however, other nutrients such as vitamin B12 (cofactor in One Carbon Metabolism), vitamin A and C, selenium, etc. were evaluated. As a result, they did not observe a significant difference between the genotypes and these other nutrients. Other related nutrients like choline were not analyzed because that was not the purpose of the study.

For all these reasons, we suggest an antioxidant-rich diet for young women with MTHFR C677T polymorphism. It provides essential nutrients like folate, an important vitamin in the regulation of inflammatory response, cell damage, DNA repair, antioxidant capacity (CAT), Hcy levels, and stability of the MTHFR enzyme [3,16,55,78-80]. Considering that nutrigenetics explains the interaction of gene-nutrients [81,82], our results corroborate with several studies that have reported the importance of personalized nutritional intervention reducing C677T polymorphism effects and preventing many diseases $[15,17,27,83-85]$.

Specifically in our study, participants tolerated well the amounts of folate-rich foods and vegetables offered. Based on many studies previously cited in the present work, we observed the use of folic acid supplementation, folate fortification, vegetable consumption, etc.; however, we did not see many studies with low folate doses ( $<400 \mathrm{mcg} /$ day) with good results. Effective changes in dietary habits that incorporate adequate amounts of nutrients such as folate need to involve educational processes, requiring investments and government efforts. According to the literature consulted, the intake of folate does not supply the EAR recommendation, so in countries where folic acid fortification is not available, insufficient intake of folic acid is more pronounced [19]. Thus, greater inadequate folate consumption would contribute to more detrimental health outcomes in individuals with the MTHFR C677T polymorphism. 
According to the "Sakado Folate Project" conducted by Kagawa et al. [57], the genotype-based personalized diet was better accepted than the general individual diet. The personalized diet was more efficient to motivate change in the participants' lifestyle and improve their nutritional status by elevating green leafy vegetables and folic acid-fortified food intake even one year after the end of the study. Nielsen; El-Sohemy [86] and Hiraoka; Kagawa [17], observed a similar effect with this type of intervention connecting genotype and folate content.

Previous studies cited above have demonstrated a high association between hyperhomocysteinemia, folic acid blood levels, and development of oxidative stress, especially for individuals with the TT genotype. However, this was the first study to show not only elevated folic acid concentrations and decreased Hcy levels but reduced inflammatory biomarkers in individuals with the C677T allele after intervention with folate.

The limitation of the study was the sample size. However, we still observed a dietary response with the highest dose of folate, even under the influence of the MTHFR C677T polymorphism. Thus, the results of this study can demonstrate the importance of considering individual information when establishing nutritional goals for specific biological responses. The control group was not used in this study because the researchers wanted to investigate which dose of folate in the natural diet had benefits for obese adult women with C677T polymorphism.

\section{Conclusions}

Based on our original results, the intervention with folate consumption $(191 \mu \mathrm{g} / \mathrm{day})$ from natural foods for eight weeks had a beneficial effect on the reduction of inflammatory markers (TNF- $\alpha$, IL-6, and IL1 $\beta$ ) and Hcy in overweight and obese women with MTHFR C677T polymorphism TT genotype. It is important to highlight why biological individuality should be considered a priority to improve people's health.

Author Contributions: Conceptualization-J.V.d.C.L., R.P.A.L., M.d.C.R.G., R.T.L., A.d.S.D. and M.J.d.C.C.; Data curation-J.V.d.C.L., M.d.C.R.G., R.C.P.L., R.P.A.L., R.A.F.d.N., M.G.C.A.M., K.Q.d.F.L. and C.P.N.d.S.F.; Formal analysis-J.V.d.C.L., M.R.R., R.C.P.L., R.P.A.L., A.d.S.D., A.T.C.d.A. and R.M.d.M.; Funding acquisition-J.V.d.C.L. and M.R.R.; Investigation-J.V.d.C.L., M.R.R., R.C.P.L., R.P.A.L., R.A.F.d.N., M.G.C.A.M., K.Q.d.F.L., C.P.N.d.S.F. and E.V.J.; Methodology-J.V.d.C.L., M.R.R., R.C.P.L., R.P.A.L., A.d.S.D. and M.J.d.C.C.; Project administration-J.V.d.C.L., M.R.R. and M.J.d.C.C.; Resources-J.V.d.C.L., M.R.R., D.C.P., R.C.V., A.S.d.S. and M.J.d.C.C.; Software-R.M.d.M.; Supervision-D.C.P. and M.J.d.C.C.; Validation-J.V.d.C.L., N.F.P.d.O., D.C.P., R.C.V., M.d.C.R.G., F.E.L.d.L.F., A.S.d.S. and M.J.d.C.C.; Visualization-J.V.d.C.L. and M.J.d.C.C.; Writing-original draft-J.V.d.C.L. and M.J.d.C.C.; Writing-review \& editing-J.V.d.C.L., M.R.R., R.C.P.L., R.P.A.L., R.A.F.d.N., M.G.C.A.M., K.Q.d.F.L., C.P.N.d.S.F., N.F.P.d.O., D.C.P., R.C.V., M.d.C.R.G., F.E.L.d.L.F., R.T.L., A.S.d.S., A.d.S.D., A.T.C.d.A., R.M.d.M., E.V.J. and M.J.d.C.C. All authors have read and agreed to the published version of the manuscript.

Funding: This work was supported by the Paraiba Research Support Foundation-FAPESQ, PB -EFP_00008187) and National Council for Scientific and Technological Development [CNPq], Ministry of Health.

Acknowledgments: We would like to acknowledge the project coordinator, Maria José de Carvalho Costa and her team composed of teachers, master's, doctoral, and undergraduate students, and research collaborators (Post-graduation program in Nutritional Sciences/Federal University of Paraíba). We thank the partners of the UFPB for the genetic analyses.

Conflicts of Interest: The authors declare that they have no competing interests.

\section{References}

1. Stover, P.J. Polymorphisms in 1-carbon metabolism, epigenetics and folate-related pathologies. J. Nutr. Nutr. 2005, 4, 293-305. [CrossRef] [PubMed]

2. Bailey, L.B.; Stover, P.J.; McNulty, H.; Fenech, M.F.; Gregory, J.F., III; Mills, J.L.; Raiten, D.J. Biomarkers of Nutrition for Development-Folate Review. J. Nutr. 2015, 145, 1636S-1680S. [CrossRef] [PubMed]

3. Ribeiro, M.R.; Lima, R.P.A.; Lisboa, J.V.C.; Chaves, T.R.; Luna, R.C.P.; do Nascimento, R.A.F.; de Oliveira, Y.; Persuhn, D.C.; Sérgio da Silva, A.; Gonçalves, M.D.C.R.; et al. Influence of the C677T Polymorphism of the MTHFR Gene on Oxidative Stress in Women With Overweight or Obesity: Response to a Dietary Folate Intervention. J. Am. Coll. Nutr. 2018, 27, 1-8. [CrossRef] [PubMed] 
4. Frosst, P.; Blom, H.J.; Milos, R.; Goyette, P.; Sheppard, C.A.; Matthews, R.G.; Boers, G.J.; den Heijer, M.; Kluijtmans, L.A.; van den Heuvel, L.P.; et al. A candidate genetic risk factor for vascular disease: A common mutation in methylenetetrahydrofolate reductase. Nat. Genet. 1995, 10, 111-113. [CrossRef]

5. Moll, S.; Varga, E.A. Homocysteine and MTHFR Mutations. Circulation 2015, 132, 6-9. [CrossRef]

6. Tsang, B.L.; Devine, O.J.; Cordero, A.M.; Marchetta, C.M.; Mulinare, J.; Mersereau, P.; Guo, J.; Qi, Y.P.; Berry, R.J.; Rosenthal, J.; et al. Assessing the association between the methylenetetrahydrofolate reductase (MTHFR) 677C $>$ T polymorphism and blood folate concentrations: A systematic review and meta-analysis of trials and observational studies. Am. J. Clin. Nutr. 2015, 101, 1286-1294. [CrossRef]

7. Holven, K.B.; Aukrust, P.; Retterstol, K.; Hagve, T.A.; Mørkrid, L.; Ose, L.; Nenseter, M.S. Increased levels of C-reactive protein and interleukin-6 in hyperhomocysteinemic subjects. Scand. J. Clin. Lab. Investing. 2006, 66, 45-54. [CrossRef]

8. Zhang, L.; Jin, M.; Hu, X.; Zhu, J. Homocysteine stimulates nuclear factor kB activity and interleukin-6 expression in rat vascular smooth muscle cells. Cell Biol. Int. 2006, 30, 592-597. [CrossRef]

9. Fuchs, D.; Avanzas, P.; Arroyo-Espliguero, R.; Jenny, M.; Consuegra-Sanchez, L.; Kaski, J.C. The role of neopterin in atherogenesis and cardiovascular risk assessment. Curr. Med. Chem. 2009, 16, 4644-4653. [CrossRef]

10. Murr, C.; Winklhofer-Roob, B.M.; Schroecksnadel, K.; Maritschnegg, M.; Mangge, H.; Böhm, B.O.; Winkelmann, B.R.; März, W.; Fuchs, D. Inverse association between serum concentrations of neopterin and antioxidants in patients with and without angiographic coronary artery disease. Atherosclerosis 2009, 202, 543-549. [CrossRef]

11. Wang, M.; Kaufman, R.J. The impact of the endoplasmic reticulum protein-folding environment on cancer development. Nat. Rev. Cancer 2014, 14, 581-597. [CrossRef] [PubMed]

12. Wu, P.; Zhang, F.; Dai, Y.; Han, L.; Chen, S. Serum TNF- $\alpha$, GTH and MDA of high-fat diet-induced obesity and obesity resistant rats. Saudi. Pharm. J. 2016, 24, 333-336. [CrossRef] [PubMed]

13. Joshi, R.; Adhikari, S.; Patro, B.S.; Chattopadhyay, S.; Mukherjee, T. Free radical scavenging behavior of folic acid: Evidence for possible antioxidant activity. Free Radic. Biol. Med. 2001, 30, 1390-1399. [CrossRef]

14. Mangge, H.; Becker, K.; Fuchs, D.; Gostner, J.M. Antioxidants, inflammation and cardiovascular disease. World J. Cardiol. 2014, 6, 462-477. [CrossRef]

15. Shiran, A.; Remer, E.; Asmer, I.; Karkabi, B.; Zittan, E.; Cassel, A.; Barak, M.; Rozenberg, O.; Karkabi, K.; Flugelman, M.Y. Association of Vitamin B12 Deficiency with Homozygosity of the TT MTH FR C677T Genotype, Hyperhomocysteinemia, and Endothelial Cell Dysfunction. Isr. Med. Assoc. J. 2015, 17, $288-292$.

16. Lee, J.Y.; Shin, C.; Baik, I. Longitudinal associations between micronutrient consumption and leukocyte telomere length. J. Hum. Nutr. Diet. 2017, 30, 236-243. [CrossRef]

17. Hiraoka, M.; Kagawa, Y. Genetic polymorphisms and folate status. Congenit. Anom. 2017, 57, $142-149$. [CrossRef]

18. Bandarra, D.; Biddlestone, J.; Mudie, S.; Müller, H.A.J.; Rocha, S. HIF-1 $\alpha$ restricts NF-kB-dependent gene expression to control innate immunity signals. Dis. Models Mech. 2015, 8, 169-181. [CrossRef]

19. Shi, M.; Caprau, D.; Romitti, P.; Christensen, K.; Murray, J.C. Genotype frequencies and linkage disequilibrium in the CEPH human diversity panel for variants in folate pathway genes MTHFR, MTHFD, MTRR, RFC1, and GCP2. Birth Defects Res. A Clin. Mol. Teratol. 2003, 67, 545-549. [CrossRef]

20. Wu, C.H.; Huang, T.C.; Lin, B.F. Folate deficiency affects dendritic cell function and subsequent T helper cell differentiation. J. Nutr. Biochem. 2017, 41, 65-72. [CrossRef]

21. Otten, J.J.; Hellwig, J.P.; Linda, D. Dietary Reference Intakes: The Essential Guide to Nutrient; National Academies Press: Washington, DC, USA, 2006; pp. 245-253.

22. Liew, S.C. Folic acid and diseases-Supplement it or not? Rev. Assoc. Med. Bras. 2016, 62, 90-100. [CrossRef] [PubMed]

23. dos Santos Nunes, M.K.; Silva, A.S.; Wanderley de Queiroga Evangelista, I.; Modesto Filho, J.; Alves Pegado Gomes, C.N.; Ferreira do Nascimento, R.A.; Pordeus Luna, R.C.; de Carvalho Costa, M.J.; Paulo de Oliveira, N.F.; Camati Persuhn, D. Analysis of the DNA methylation profiles of miR-9-3, miR-34a, and miR-137 promoters in patients with diabetic retinopathy and nephropathy. J. Diabetes Complicat. 2018, 32, 593-601. [CrossRef] [PubMed] 
24. Costa, M.J.C. Resultado Final PPSUS 2013. II Ciclo de Diagnóstico e Intervenção da Situação Alimentar, Nutricional e das Doenças não Transmissíveis mais Prevalentes da População do Município de João Pessoa/PB [Cycle II of Diagnosis and Intervention of the Food, Nutritional and Non-Communicable Diseases Status of the Population of the Municipality of João Pessoa (II DISANDNT/JP)]. João Pessoa: Foundation for Support and Research Support/PPSUS/PB/Ministry of Health/National Research Council/CNPq/João Pessoa Prefecture. Public Notice 001/2013, Number EFP_00008187. Available online: http://fapesq.rpp.br/editaisresultados/resultadofinalppsus2013.pdf/view (accessed on 9 July 2019).

25. Bolfarine, H.; Bussab, W. de O. Sampling Elements, 1st ed.; Edgard Blucher: São Paulo, Brazil, 2005.

26. de Medeiros Cavalcante, I.G.; Silva, A.S.; Costa, M.J.; Persuhn, D.C.; Issa, C.T.; de Luna Freire, T.L.; da Conceição Rodrigues Gonçalves, M. Effect of vitamin D3 supplementation and influence of BsmI polymorphism of the VDR gene of the inflammatory profile and oxidative stress in elderly women with vitamin D insufficiency: Vitamin D3 megadose reduces inflammatory markers. Exp. Gerontol. 2015, 66, 10-16. [CrossRef] [PubMed]

27. Massa, N.M.L.; Silva, A.S.; de Oliveira, C.V.C.; Costa, M.J.C.; Persuhn, D.C.; Barbosa, C.V.S.; Gonçalves, M.D. Supplementation with Watermelon Extract Reduces Total Cholesterol and LDL Cholesterol in Adults with Dyslipidemia under the Influence of the MTHFR C677T Polymorphism. J. Am. Coll. Nutr. 2016, 35, 514-520. [CrossRef]

28. Issa, C.T.M.I.; Silva, A.S.; Toscano, L.T.; Medeiros, M.S.; Persuhn, D.C.; da Silva Diniz, A.; de Carvalho Costa, M.J.; Rodrigues Gonçalves Mda, C. Relationship between cardiometabolic profile, vitamin D status and BsmI polymorphism of the VDR gene in non-institutionalized elderly subjects: Cardiometabolic profile, vitamin D status and BsmI polymorphism of the VDR gene in non-institutionalized elderly subjects. Exp. Gerontol. 2016, 81, 56-64.

29. Cohen, J. Statistical Power Analysis for the Behavioral Sciences, 2nd ed.; Lawrence Erlbaum: Hillsdale, MI, USA, 1988.

30. Switzeny, O.J.; Müllner, E.; Wagner, K.H.; Brath, H.; Aumüller, E.; Haslberger, A.G. Vitamin and antioxidant rich diet increases MLH1 promoter DNA methylation in DMT2 subjects. Clin. Epigenet. 2012, 4, 19. [CrossRef]

31. National Cholesterol Education Program (NCEP) Expert Panel on Detection, Evaluation and T of HBC in A (Adult TPI. Third Report of the National Cholesterol Education Program (NCEP) Expert Panel on Detection, Evaluation, and Treatment of High Blood Cholesterol in Adults (Adult Treatment Panel III) final report. Circulation 2002, 106, 3143-3421.

32. Lichtenstein, A.H.; Appel, L.J.; Brands, M.; Carnethon, M.; Daniels, S.; Franch, H.A.; Franklin, B.; Kris-Etherton, P.; Harris, W.S.; Howard, B.; et al. Diet and lifestyle recommendations revision 2006: A scientific statement from the American heart association nutrition committee. Circulation 2006, 114, 82-96. [CrossRef]

33. Dietary Guidelines Advisory Committee. Report of the Dietary Guidelines Advisory Committee on the Dietary Guidelines for Americans. Part D: The Science Base. Section 2: Nutrient Adequacy; USDA: Washington, DC, USA, 2010.

34. Costa, M.J.C. Nutrição Clínica: Uso do Sistema de Equivalentes na Prática Dietoterápica, 2nd ed.; Editora da UFPB: João Pessoa, Brazil, 2013.

35. World Health Organization. Physical Status: The Use and Interpretation of Anthropometry; Report of A WHO Expert Committee; WHO: Geneva, Switzerland, 1995.

36. Kuo, K.; Still, R.; Mcdowell, I.; Biochem, M. Standardization (External and Internal) of HPLC Assay for Plasma Homocysteine. Clin. Chem. 1997, 43, 1653-1669. [CrossRef]

37. Pfeiffer, C.M.; Huff, D.L.; Gunter, E.W. Rapid and accurate HPLC assay for plasma total homocysteine and cysteine in a clinical laboratory setting. Clin. Chem. 1999, 45, 290-292. [CrossRef]

38. Elefteriades, J.A. Mini-CABG: A step forward or backward? The point of view. J. Cardiothorac. Vasc. Anesth. 1997, 11, 661-668. [CrossRef]

39. Kroegel, C.; Antony, V.B. Immunobiology of pleural inflammation: Potential implications for pathogenesis, diagnosis and therapy. Eur. Respir. J. 1997, 10, 2411-2418. [CrossRef] [PubMed]

40. Xirouchaki, N.; Tzanakis, N.; Bouros, D.; Kyriakou, D.; Karkavitsas, N.; Alexandrakis, M.; Siafakas, N. Diagnostic value of interleukin-1alpha, interleukin-6, and tumor necrosis factor in pleural effusions. Chest 2002, 121, 815-820. [CrossRef] [PubMed] 
41. Benitez, J.M.; Barros, R.T.; Cevallos, C.V.G.; Rizzo, L.V.; Kokron, C.; Woronik, V.; Kalil, M.B.J. Comparação da secreção de citocinas (IL-4, IL-5, IL-6, IL-10) entre pacientes com nefropatia da IgA e deficiência de IgA. Rev. Bras. Alerg Imunopatol. 2004, 27, 82-93.

42. Junqueira, C.L.C.; Pereira De Sant'Anna, P.R.; Junqueira Monteiro, A.S.; Franco de Oliverira, J.M.; Martins Romêo Filho, L.S. Associação de Marcadores Inflamatórios e Níveis Tensionais em Indivíduos Hipertensos com Diabetes Mellitus Tipo 2 Inflammatory Markers and Blood Pressure Levels in Hypertensive Patients with Type 2 Diabetes. Rev. da SOCERJ 2005, 18, 392-396.

43. de Carvalho Pereira, D.; Lima, R.P.A.; de Lima, R.T.; Gonçalves, M.D.C.R.; de Morais, L.C.S.L.; Franceschini, S.D.C.C.; Filizola, R.G.; de Moraes, R.M.; Asciutti, L.S.R.; de Carvalho Costa, M.J. Association between obesity and calcium:phosphorus ratio in the habitual diets of adults in a city of Northeastern Brazil: An epidemiological study. Nutr. J. 2013, 12, 90. [CrossRef]

44. Asciutti, L.S.R.; Rivera, M.A.A.; Costa, M.J.C.; Lima, F.E.L.; Imperiano, E.; Arruda, M.S.; Bandeira, M.G.; Arruda, N.S. Manual de Porções Média em Tamanho Real Baseado No Programa Dietsys Para Estudo de Base Populacional; de Nutrição, D., Ed.; Universidade Federal da Paraíba: João Pessoa, Brazil, 2005.

45. USDA. U. S. Department of Agriculture Agricultural Research Service: Fontes de Folato. 2015. Available online: https://ndb.nal.usda.gov/ndb/search/list (accessed on 17 November 2017).

46. EPIC-European Prospective Investigation into Cancer and Nutrition. Multiple Source Method-MSM. Available online: https://msm.dife.de/tps/msm/ (accessed on 17 December 2017).

47. MSM. The Multiple Source Method. Departament of Epidemiology of the German Institute of Human Nutrition Potsdam. Available online: https://msm.dife.de/tps/msm/ (accessed on 17 November 2017).

48. Miller, S.A.; Dykes, D.D.; Polesky, H.F. A simple salting out procedure for extracting DNA from human nucleated cells. Nucleic Acids Res. 1988, 16, 1215. [CrossRef]

49. Arruda, V.R.; von Zuben, P.M.; Chiaparini, L.C.; Annichino-Bizzacchi, J.M.; Costa, F.F. The mutation Ala677> Val in the methylene tetrahydrofolate reductase gene: A risk factor for arterial disease and venous thrombosis. Thromb. Haemost. 1997, 77, 818-821. [CrossRef]

50. Venn, B.J.; Mann, J.L.; Williams, S.M.; Riddell, L.J.; Chisholm, A.; Harper, M.J.; Aitken, W.; Rossaak, J.L. Assessment of three levels of folic acid on serum folate and plasma homocysteine: A randomised placebo-controlled double-blind dietary intervention trial. Eur. J. Clin. Nutr. 2002, 56, 748-754. [CrossRef]

51. Ashfield-Watt, P.A.L.; Pullin, C.H.; Whiting, J.M.; Clark, Z.E.; Moat, S.J.; Newcombe, R.G.; Burr, M.L.; Lewis, M.J.; Powers, H.J.; McDowell, I.F.W. Methylenetetrahydrofolate reductase 677CT genotype modulates homocysteine responses to a folate-rich diet or a low dose folic acid supplement: A randomized controlled trial. Am. J. Clin. Nutr. 2002, 76, 180-186. [CrossRef]

52. Ashfield-Watt, P.A.L.; Whiting, J.M.; Clark, Z.E.; Moat, S.J.; Newcombe, R.G.; Burr, M.L.; McDowell, I.F.W. A comparison of the effect of advice to eat either " 5 -a-day" fruit and vegetables or folic acid-fortified foods on plasma folate and homocysteine. Eur. J. Clin. Nutr. 2003, 57, 316-323. [CrossRef] [PubMed]

53. Verhoef, P.; de Groot, L.C. Dietary determinants of plasma homocysteine concentrations. Semin. Vasc. Med. 2005, 5, 110-123. [CrossRef] [PubMed]

54. Bogers, R.P.; Dagnelie, P.C.; Bast, A.; van Leeuwen, M.; van Klaveren, J.D.; van den Brandt, P.A. Effect of increased vegetable and fruit consumption on plasma folate and homocysteine concentrations. Nutrition 2007, 23, 97-102. [CrossRef] [PubMed]

55. Kawashima, A.; Madarame, T.; Koike, H.; Komatsu, Y.; Wise, J.A. Four week supplementation with mixed fruit and vegetable juice concentrates increased protective serum antioxidants and folate and decreased plasma homocysteine in Japanese subjects. Asia Pac. J. Clin. Nutr. 2007, 16, 411-421. [PubMed]

56. Zappacosta, B.; Mastroiacovo, P.; Persichilli, S.; Pounis, G.; Ruggeri, S.; Minucci, A.; Carnovale, E.; Andria, G.; Ricci, R.; Scala, I.; et al. Homocysteine Lowering by Folate-Rich Diet or Pharmacological Supplementations in Subjects with Moderate hyperhomocysteinemia. Nutrients 2013, 5, 1531-1543. [CrossRef]

57. Kagawa, Y.; Hiraoka, M.; Kageyama, M.; Kontai, Y.; Yurimoto, M.; Nishijima, C.; Sakamoto, K. Medical cost savings in Sakado City and worldwide achieved by preventing disease by folic acid fortification. Congenit. Anom. 2017, 57, 157-165. [CrossRef]

58. Brouwer, I.A.; van Dusseldorp, M.; Thomas, C.M.; Duran, M.; Hautvast, J.G.A.J.; Eskes, T.K.A.B.; Steegers-Theunissen, R.P. Lowdose folic acid supplementation decreases plasma homocysteine concentrations: A randomized trial. Am. J. Clin. Nutr. 1999, 69, 99-104. [CrossRef] 
59. Arias, L.D.; Parra, B.E.; Muñoz, A.M.; Cárdenas, D.L.; Duque, T.G.; Manjarrés, L.M. Study Exploring the Effects of Daily Supplementation with $400 \mu \mathrm{g}$ of Folic Acid on the Nutritional Status of Folate in Women of Reproductive Age. Birth Defects Res. 2017, 109, 564-573. [CrossRef]

60. Anderson, C.A.; Beresford, S.A.; McLerran, D.; Lampe, J.W.; Deeb, S.; Feng, Z.; Motulsky, A.G. Response of serum and red blood cell folate concentrations to folic acid supplementation depends on methylenetetrahydrofolate reductase C677T genotype: Results from a crossover trial. Mol. Nutr. Food Res. 2013, 57, 637-644. [CrossRef]

61. Hiraoka, M.; Kato, K.; Saito, Y.; Yasuda, K.; Kagawa, Y. Gene-nutrient and gene-gene interactions of controlled folate intake by Japanese women. Biochem. Biophys. Res. Commun. 2004, 316, 1210-1216. [CrossRef]

62. Cabo, R.; Hernes, S.; Slettan, A.; Haugen, M.; Ye, S.; Blomhoff, R.; Mansoor, M.A. Effect of genetic polymorphisms involved in folate metabolism on the concentration of serum folate and plasma total homocysteine (p-tHcy) in healthy subjects after short-term folic acid supplementation: A randomized, double blind, crossover study. Genes Nutr. 2015, 10, 456. [CrossRef] [PubMed]

63. Colson, N.J.; Naug, H.L.; Nikbakht, E.; Zhang, P.; McCormack, J. The impact of MTHFR 677 C/T genotypes on folate status markers: A meta-analysis of folic acid intervention studies. Eur. J. Nutr. 2017, 56, 247-260. [CrossRef] [PubMed]

64. Guinotte, C.L.; Burns, M.G.; Axume, J.A.; Hata, H.; Urrutia, T.F.; Alamilla, A.; McCabe, D.; Singgih, A.; Cogger, E.A.; Caudill, M.A. Methylenetetrahydrofolate reductase $677 \mathrm{C}->$ T variant modulates folate status response to controlled folate intakes in young women. J. Nutr. 2003, 133, 1272-1280. [CrossRef] [PubMed]

65. Saldanha, J.F.; de O Leal, V.; Stenvinkel, P.; Carraro-Eduardo, J.C.; Mafra, D. Resveratrol: Why Is It a Promising Therapy for Chronic Kidney Disease Patients? Oxid. Med. Cell. Longev. 2013, 2013, 1-6. [CrossRef]

66. Connaughton, R.M.; McMorrow, A.M.; McGillicuddy, F.C.; Lithander, F.E.; Roche, H.M. Impact of anti-inflammatory nutrients on obesity-associated metabolic-inflammation from childhood through to adulthood. Proc. Nutr. Soc. 2016, 75, 115-124. [CrossRef]

67. Wang, G.; Dai, J.; Mao, J.; Zeng, X.; Yang, X.; Wang, X. Folic acid reverses hyper-responsiveness of LPS-induced chemokine secretion from monocytes in patients with hyperhomocysteinemia. Atherosclerosis 2005, 179, 395-402. [CrossRef]

68. Singhal, G.; Jaehne, E.J.; Corrigan, F.; Toben, C.; Baune, B.T. Inflammasomes in neuroinflammation and changes in brain function: A focused review. Front. Neurosci. 2014, 8, 315. [CrossRef]

69. Bonfigli, A.R.; Spazzafumo, L.; Prattichizzo, F.; Bonafè, M.; Mensà, E.; Micolucci, L.; Giuliani, A.; Fabbietti, P.; Testa, R.; Boemi, M. Leukocyte telomere length and mortality risk in patients with type 2 diabetes. Oncotarget 2016, 7, 50835-50844. [CrossRef]

70. Kim, S.; Keku, T.O.; Martin, C.; Galanko, J.; Woosley, J.T.; Schroeder, J.C.; Satia, J.A.; Halabi, S.; Sandler, R.S. Circulating Levels of Inflammatory Cytokines and Risk of Colorectal Adenomas. Cancer Res. 2008, 68, 323-328. [CrossRef]

71. Soria, G.; Ofri-Shahak, M.; Haas, I.; Yaal-Hahoshen, N.; Leider-Trejo, L.; Leibovich-Rivkin, T.; Weitzenfeld, P.; Meshel, T.; Shabtai, E.; Gutman, M.; et al. Inflammatory mediators in breast cancer: Coordinated expression of TNF $\alpha$ \& IL-1 $\beta$ with CCL2 \& CCL5 and effects on epithelial-to-mesenchymal transition. BMC Cancer 2011, 11,130 .

72. Hehlgans, T.; Pfeffer, K. The intriguing biology of the tumour necrosis factor/tumour necrosis factor receptor superfamily: Players, rules and the games. Immunology 2005, 115, 1-20. [CrossRef] [PubMed]

73. Serhan, C.N.; Chiang, N.; Van Dyke, T.E. Resolving inflammation: Dual anti-inflammatory and pro-resolution lipid mediators. Nat. Rev. Immunol. 2008, 8, 349-361. [CrossRef] [PubMed]

74. Lyons, C.L.; Kennedy, E.B.; Roche, H.M. Metabolic Inflammation-Differential Modulation by Dietary Constituents. Nutrients 2016, 8, 247. [CrossRef] [PubMed]

75. Farinha, J.B.; Steckling, F.M.; Stefanello, S.T.; Cardoso, M.S.; Nunes, L.S.; Barcelos, R.P.; Duarte, T.; Kretzmann, N.A.; Mota, C.B.; Bresciani, G. Response of oxidative stress and inflammatory biomarkers to a 12-week aerobic exercise training in women with metabolic syndrome. Sports Med. Open 2015, 1, 3. [CrossRef] [PubMed]

76. Huang, C.J.; Mcallister, M.J.; Slusher, A.L.; Webb, H.E.; Mock, J.T.; Acevedo, E.O. Obesity-related oxidative stress: The impact of physical activity and diet manipulation. Sports Med. Open 2015, 1, 32. [CrossRef] [PubMed] 
77. Qin, X.; Li, J.; Cui, Y.; Liu, Z.; Zhao, Z.; Ge, J.; Guan, D.; Hu, J.; Wang, Y.; Zhang, F.; et al. MTHFR C677T and MTR A2756G polymorphisms and the homocysteine lowering efficacy of different doses of folic acid in hypertensive Chinese adults. Nutr. J. 2012, 11, 2. [CrossRef]

78. Cuskelly, G.J.; McNulty, H.; Scott, J.M. Effect of increasing dietary folate on red-cell folate: Implications for prevention of neural tube defects. Lancet 1996, 347, 657-659. [CrossRef]

79. Bonaa, K.H.; Njølstad, I.; Ueland, P.M.; Schirmer, H.; Tyerdal, A.; Steigen, T.; Wang, H.; Nordrehaug, J.E.; Arnesen, E.; Rasmussen, K. Homocysteine lowering and cardiovascular events after acute myocardial infarction. N. Engl. J. Med. 2006, 354, 1578-1588. [CrossRef]

80. Abd-Elmawla, M.A.; Rizk, S.M.; Youssry, I.; Shaheen, A.A. Impact of genetic polymorphism of methylenetetrahydrofolate reductase $\mathrm{C} 677 \mathrm{~T}$ on development of hyperhomocysteinemia and related oxidative changes in Egyptian b-thalassemia major patients. PLoS ONE 2016, 11, e0155070. [CrossRef]

81. McDonald, D.; Glusman, G.; Price, N.D. Personalized nutrition through big data. Nat. Biotechnol. 2016, 34, 152-154. [CrossRef]

82. Noecker, C.; Borenstein, E. Getting Personal about Nutrition. Trends Mol. Med. 2016, 22, 83-85. [CrossRef] [PubMed]

83. Jacka, F.N.; Maes, M.; Pasco, J.A.; Williams, L.J.; Berk, M. Nutrient intakes and the common mental disorders in women. J. Affect. Disord. 2012, 141, 79-85. [CrossRef] [PubMed]

84. Vollset, S.E.; Clarke, R.; Lewington, S.; Ebbing, M.; Halsey, J.; Lonn, E.; Armitage, J.; Manson, J.E.; Hankey, G.J.; Spence, J.D.; et al. Effects of folic acid supplementation on overall and site-specific cancer incidence during the randomised trials: Meta-analyses of data on 50,000 individuals. Lancet 2013, 381, 1029-1036. [CrossRef]

85. Clarke, R.; Bennett, D.; Parish, S.; Lewington, S.; Skeaff, M.; Eussen, S.J.; Lewerin, C.; Stott, D.J.; Armitage, J.; Hankey, G.J.; et al. Effects of homocysteine lowering with B vitamins on cognitive aging: Metaanalysis of 11 trials with cognitive data on 22,000 individuals. Am. J. Clin. Nutr. 2014, 100, 657-666. [CrossRef]

86. Nielsen, D.E.; El-Sohemy, A. A randomized trial of genetic information for personalized nutrition. Genes Nutr. 2012, 7, 559-566. [CrossRef]

(C) 2020 by the authors. Licensee MDPI, Basel, Switzerland. This article is an open access article distributed under the terms and conditions of the Creative Commons Attribution (CC BY) license (http://creativecommons.org/licenses/by/4.0/). 